\title{
Anaerobic Gram Negative Coccus
}

National Cancer Institute

\section{Source}

National Cancer Institute. Anaerobic Gram Negative Coccus. NCI Thesaurus. Code C86143.

Any spherical shaped bacteria that does not require oxygen to grow or respirate and has a cell wall that contains low levels of peptidoglycan and stains pink with the Gram staining technique. 